\title{
MMP-9 Level Comparation between Spontaneous Abortion and Normal Pregnancy
}

\author{
Aloysius Suryawan ${ }^{1 *}$, Johanes C.Mose ${ }^{1}$, Budi Handono ${ }^{1}$ \\ ${ }^{1}$ Obstetrics \& Gynecology Department, Fetomaternal Department, \\ Medical Faculty Padjadjaran University/Hasan Sadikin Hospital, Jl. Pasteur No. 38, Bandung \\ *e-mail: theresia_rahardjo@hotmail.com
}

\section{Abstract}

B ACKGROUND: Abortion remains a problem in the obstetric care as it is one of the causes of maternal and fetal death. Bleeding or miscarriage threat in the first trimester comprises $20 \%$ to $25 \%$ of all pregnant women, and $50 \%$ of them will end as spontaneous abortion. The major cause of maternal death in abortion is hemorrhage. Some recent studies have indicated that MMP-9 is important in the process of embryo implantation into the endometrium and spontaneous abortion occurs when there is an overwhelming increase of MMP-9. This data indicate the importance of a further research to elucidate the role of MMP-9 in spontaneous abortion.

METHODS: This was a cross sectional study, included 70 pregnant women with gestational age $<20$ weeks who came for examination and treatment at the Department of Obstetrics and Gynecology, Medical Faculty of Padjadjaran University/Hasan Sadikin Hospital, Bandung

RESULTS: There were differences in the MMP-9 levels in spontaneous abortion compared to normal pregnancy and MMP-9 had a cut-off point $>1221.7$ with the sensitivity of $48.6 \%$, specificity of $80 \%$, and accuracy of $60.9 \%$.

SUMMARY: The MMP-9 level in spontaneous abortion was higher than in normal pregnancy.

KEYWORDS: MMP-9, spontaneous abortion, normal pregnancy

Indones Biomed J 2012; 4 (3): 174-179

\section{Abstrak}

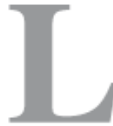

ATAR BELAKANG: Abortus selalu menjadi masalah dalam perawatan obstetric karena merupakan salah satu penyebab kematian ibu dan anak. Perdarahan atau ancaman abortus pada trimester pertama sekitar $20 \%$ sampai $25 \%$ dari semua wanita hamil, dan $50 \%$ akan berakhir sebagai abortus spontan. Sebab utama dari kematian ibu pada abortus adalah perdarahan. Beberapa penelitian mengindikasikan bahwa MMP-9 sangat penting dalam proses implantasi embrio ke dalam endometrium dan abortus spontan terjadi bila ada peningkatan berlebihan dari MMP-9. Data ini mendukung diadakannya penelitian lebih lanjut untuk memperjelas peran MMP-9 dalam abortus spontan.

METODE: Penelitian Cross sectional, meliputi 70 wanita hamil dengan usia kehamilan $<20$ minggu yang datang untuk pemeriksaan dan terapi di Bagian Obstetri dan Ginekologi Fakultas Kedokteran Universitas Padjadjaran/ RS Hasan Sadikin Bandung.

HASIL: Terdapat perbedaan kadar MMP-9 pada abortus spontan dibandingkan dengan kehamilan normal dan MMP-9 memiliki titik potong $>1221.7$ dengan sensitivitas $48.6 \%$, spesifisitas $80 \%$ dan akurasi $60.9 \%$.

KESIMPULAN: Kadar MMP-9 pada abortus spontan lebih tinggi daripada kehamilan normal.

KATA KUNCI: KATA KUNCI : MMP-9, abortus spontan, kehamilan normal

Indones Biomed J 2012; 4 (3): 174-179 


\section{Introduction}

Abortion is the spontaneous loss of pregnancy before 20 weeks of gestation (UK). Abortion is a common complication of pregnancy and approximately $25 \%$ of women have experienced spontaneous abortion. Bleeding or miscarriage threat in the first trimester was found in $20 \%$ to $25 \%$ of all pregnant women, and about $50 \%$ of them will end up with spontaneous abortion (1). In some hospitals in Indonesia, the incidence of abortion varies between $2.5-15 \%$ and the maternal deaths due to abortion ranges from 1-1.5\% (1,2). In Hasan Sadikin Hospital Bandung, from year to year the prevalence of abortion accounts for 6.5 to $15 \%$, with a maternal mortality rate of $1-2 \%$ of all maternal deaths. The main causes of maternal deaths are due to hemorrhage.

Implantation of the embryo is a major factor determining fertility. Factors that play a role in the successful embryo implantation are not fully understood, but it seems that role of hormones and cytokines is to affecti implantation and maintaining pregnancy $(3,4,5)$.

Pregnancy causes a change in the systems of Th1 and Th2 and vascular endothelial condition, which results in the release of MMP-2 and MMP-9. MMP-2 and MMP-9 are especially involved in successful cytotrophoblast invasion in early pregnancy as they are considered key enzymes in degradation of basement membrane, which mainly consists of type IV collagen. Tissue inhibitors for MMPs, such as TIMP-1 and TIMP-2, regulate protease activity to prevent overwhelmed destruction of endometrium. MMP2 and MMP-9 with their tissue inhibitors (TIMPs) form a balance to maintain normal early pregnancy and placental development.

In normal pregnancy, this process will stop after the embryo implantation succeeds, but if this change goes on and endometrium destruction continues, it will involve more cytokine release that will stimulate a continued release of MMP-2 and MMP-9. This condition can lead to widespread extracellular matrix components degradation, hence finally the abortion can occur (6-12).
Research on the role of MMP-9 and TIMPs in sustaining pregnancy in its early stage needs to be further carried out. Some recent studies have shown a spontaneous abortion occurs when there is an imbalance of MMP-9 and TIMPs levels. Successful embryo implantation process needs endometrium destruction and MMP-9 has an important role in this destruction process through extracellular matrix component degradation. This is a very complex process involving many cytokines in the endometrium and change from pro MMP to active MMP. MMP-9 also plays an important role in capillary endothelium degradation. A meta-analysis conducted by Zhao et al. in 2005 suggested a link between inhibin A, activin, MMP-2 and MMP-9 in the failure of implantation. Zhao found that MMP-9 blockade might inhibit the process of abortion in murine (9-13).

Based on these data, MMP-9 level might be used as a marker of successful pregnancy. Studies of MMP-9 level in abortion are still very few, so further research is needed to provide explanations and answers to the issues $(6,9)$.

\section{Methods}

\section{Design of study: \\ Cross sectional study.}

\section{Selection of Samples}

This study included 70 pregnant women with $<20$ weeks pregnancy that came for examination and treatment at the Department of Obstetrics and Gynecology Medical Faculty of Padjadjaran University/Hasan Sadikin Hospital Bandung and fulfilled the inclusion and exclusion criteria. Inclusion criteria were: single pregnancy, alive or dead fetus, bleeding complaints, gestational age 10-20 weeks, maternal body mass index in normal range, willing to fulfill the research, and having a clear address, town or district in Bandung, and easy to contact. Exclusion criteria included fetal congenital abnormality by USG, uterus abnormality by USG, infection, missed abortion, hydatiform mole, 
ectopic pregnancy, and provocation abortion. Sample size was determined with two proportion calculation and the result was 35 women for each group, so the total sample was 70 pregnant women.

\section{Research protocol}

Blood sample collection. Seventy cases that met the study criteria were divided into two groups: 35 pregnant women in group I were women with normal pregnancies (10-20 weeks pregnancy) and group II who experienced spontaneous abortion. Blood samples for MMP-9 examination were drawn from the media cubital vena around $10 \mathrm{cc}$ with EDTA tube using vacutainer. Blood samples could be stored for 5 days at $2^{\circ}-8^{\circ} \mathrm{C}$, until the examination. The blood samples were then sent to Prodia Laboratory Wastukencana Bandung to be forwarded to Prodia Laboratory Center Jakarta.

MMP-9 examination. MMP-9 calculation using Total MMP-9 Microplate (lot 269859) 96 wells of polystyrene microplates (12 strip of 8 well) coated with a mouse monoclonal antibody against human MMP-9 with R \& D systems.

\section{Data Analysis}

Statistical data analysis used was chi square test to compare the differences in two proportions. All calculations were done using the software SPSS 13.0 for Windows version. Statistical test of significance was determined by the value of $\varrho<0.05$.

\section{Research Ethics}

This study was done after approval from the Head of Obstetric and Gynecology Department of Medical Faculty of Maranatha Christian University Bandung, the Director of Immanuel Hospital Bandung, and the Head of Fetomaternal Sub Department of Medical Faculty of Padjadjaran University/Hasan Sadikin Hospital Bandung. Ethical approval was obtained from the Ethical Committee of Medical Faculty of Padjadjaran University/Hasan Sadikin Hospital Bandung. All participants gave informed consents and were chosen in the study on a voluntary basis.

\section{Results}

\section{Subjects characteristics}

Subjects characteristics of the abortion group and normal pregnancy group including age, pregnancy, and IMT were analyzed to prove subject homogeneity.

\section{Table 1. Subjects characteristics between abortion group and normal pregnancy group}

\begin{tabular}{cccc}
\hline & \multicolumn{2}{c}{ Research Group } \\
Characteristics & $\begin{array}{c}\text { Spontaneous Abortion } \\
(\mathbf{n}=\mathbf{3 5})\end{array}$ & $\begin{array}{c}\text { Normal Pregnancy } \\
(\mathbf{n}=\mathbf{3 5})\end{array}$ & Statistic Test \\
\hline Age (year) : & & & \\
$<25$ & $7(20)$. & $12(34.3)$ & $\mathbf{t}=\mathbf{1 . 3 0}$ \\
$25-35$ & $15(42.9)$ & $14(40.0)$ & $\mathbf{p}=\mathbf{0 . 1 9 8}$ \\
$>35$ & $13(37.1)$ & $9(25.7)$ & \\
Mean (SD) & $31.5(7.9)$ & $29.0(8.3)$ & \\
Range & $17-46$ & $14-45$ & $\mathbf{p}=0.951$ \\
Pregnancy & & $15(42.9)$ & \\
1 & $14(40.0)$ & $13(37.1)$ & \\
2 & $13(37.1)$ & $7920.0)$ & $\mathrm{t}=0.113$ \\
3 & $8(22.9)$ & & $\mathrm{p}=0.910$ \\
IMT (kg/m $\left.{ }^{2}\right):$ & & $28.38(2.38)$ & \\
Mean (SD) & $28.32(2.04)$ & $25.3-38.5$ & \\
Range & $25.0-32.8$ & & \\
\hline
\end{tabular}

$\chi 2=$ chi square test; $\mathrm{t}=\mathrm{t}$ test; based on $\mathrm{p} \leq 0,05$ 
The statistical analysis in Table 1 shows that both groups are homogenous based on age, pregnancy, and IMT. Table 1 also shows that the most vulnerable age is 25 to 35 years accounting for $42.9 \%$, first pregnancy (primigravida) as $40 \%$ and IMT $\left(\mathrm{kg} / \mathrm{m}^{2}\right)$ of 25.0 to 32.8 .

Table 2 shows the laboratory results of abortion group and normal pregnancy group. This Table shows that there were no statistically significant differences in laboratory tests such as hemoglobin, platelets, and hematocrit, with $\mathrm{p}>0.05$ for each value. Statistical results from these two Tables show that the two groups were homogenous.

Table 3 shows differences of MMP-9 levels in normal pregnancy and spontaneous abortion groups. The mean of MMP-9 level was 1240.5 in spontaneous abortion group and 975.6 in normal pregnancy group. This result was tested with Mann-Whitney test and proved statistically significant at $\mathrm{p}=0.025$.

\section{Table 2. Laboratory results of abortion group and normal pregnancy group}

\begin{tabular}{|c|c|c|c|}
\hline \multicolumn{4}{|c|}{ Research Group } \\
\hline Characteristics & $\begin{array}{l}\text { Spontaneous Abortion } \\
\qquad(\mathrm{n}=35)\end{array}$ & $\begin{array}{l}\text { Normal Pregnancy } \\
\quad(n=35)\end{array}$ & Statistic Test \\
\hline \multicolumn{4}{|l|}{ 1. $\mathrm{Hb}(\mathrm{gr} / \mathrm{dL})$ : } \\
\hline Mean (SD) & $10.97(1.40)$ & $10.88(1.31)$ & $t=0.253$ \\
\hline Median & 10.7 & 10.7 & $p=0.801$ \\
\hline Range & $8.7-14.4$ & $8.3-13.3$ & \\
\hline \multicolumn{4}{|c|}{ 2. Leucocyte (/uL): } \\
\hline Mean (SD) & 12432 (2992) & $16000(14629)$ & $Z_{M-W}=1.686$ \\
\hline Median & 12100 & 13700 & $p=0.092$ \\
\hline Range & $7600-18600$ & $5900-97500$ & \\
\hline \multicolumn{4}{|c|}{ 3. Trombocyte (/uL): } \\
\hline Mean (SD) & 234380 (110392) & 249257 (57616) & $Z_{M-W}=1.063$ \\
\hline Median & 215000 & 235000 & $p=0.288$ \\
\hline Range & $27600-475000$ & $174000-397000$ & \\
\hline \multicolumn{4}{|l|}{ 4. $\mathrm{Ht}(\%)$ : } \\
\hline Mean (SD) & $34.94(4.69)$ & 33.77 (5.69) & $Z_{M-W}=0.024$ \\
\hline
\end{tabular}

Note: $\mathrm{t}=t$ test; $\mathrm{Z}_{\mathrm{M}-\mathrm{w}}=$ Mann-Whitney test.

Table 3. Comparison of MMP-9 levels between spontaneous abortion group and normal pregnancy group

\begin{tabular}{lccc}
\hline $\begin{array}{c}\text { MMP-9 level } \\
(\mathrm{mmol} / \mathrm{L})\end{array}$ & $\begin{array}{c}\text { Spontaneous Abortion } \\
(\mathbf{n}=\mathbf{3 5})\end{array}$ & $\begin{array}{c}\text { Normal Pregnancy } \\
(\mathbf{n}=\mathbf{3 5})\end{array}$ & Statistic Test \\
\hline Mean (SD) & $1240.5(441)$. & $975.6(318.1)$ & $\mathrm{Z}_{\mathrm{M}-\mathrm{W}}=2.244$ \\
Median & 1215.7 & 1041.5 & $\mathrm{p}=0.025$ \\
Range & $735-2156.5$ & $392.6-1520.6$ & \\
& & & \\
\hline
\end{tabular}

Note: $\mathrm{Z}_{\mathrm{M}-\mathrm{N}}$ (Mann-Whitney test). 


\section{Table 4. Correlation between variables with MMP-9 levels in spontaneous abortion group and normal pregnancy group}

\begin{tabular}{|c|c|c|c|c|}
\hline \multirow{2}{*}{$\begin{array}{c}\text { Variables correlated with } \\
\text { MMP-9 level }\end{array}$} & \multicolumn{2}{|c|}{$\begin{array}{l}\text { Spontaneous Abortion } \\
\qquad(\mathrm{n}=35)\end{array}$} & \multicolumn{2}{|c|}{$\begin{array}{l}\text { Normal Pregnancy } \\
\quad(n=35)\end{array}$} \\
\hline & $r_{s}$ & Nilai $\mathbf{p}^{*}$ ) & $r_{s}$ & Nilai $\mathbf{p}^{*}$ ) \\
\hline Age & 0.014 & 0.936 & 0.068 & 0.697 \\
\hline IMT & -0.264 & 0.025 & 0.372 & 0.028 \\
\hline $\mathrm{Hb}$ & -0.093 & 0.597 & -0.004 & 0.984 \\
\hline Leucocyte & 0.292 & $\left.0.044^{* *}\right)$ & 0.235 & 0.175 \\
\hline Trombocyte & -0.143 & 0.413 & 0.048 & 0.786 \\
\hline $\mathrm{Ht}$ & -0.071 & 0.687 & 0.095 & 0.588 \\
\hline
\end{tabular}

Note: $r_{\mathrm{s}}=$ rank Spearman correlation. * ) two side test. ${ }^{* *}$ ) one side test.

Table 5. Correlation between MMP-9 levels (cut off value) with spontaneous abortion

\begin{tabular}{cccc}
\hline & \multicolumn{2}{c}{ Research Group } \\
$\begin{array}{c}\text { MMP-9 level } \\
(\mathrm{mmol} / \mathrm{L})\end{array}$ & $\begin{array}{c}\text { Spontaneous Abortion } \\
(\mathbf{n = 3 5 )}\end{array}$ & $\begin{array}{c}\text { Normal Pregnancy } \\
(\mathbf{n}=\mathbf{3 5})\end{array}$ & Statistic Test \\
\hline 1221.7 & 17 & 7 & $\mathrm{X}^{2}=6.341$ \\
$\leq 1221.7$ & 18 & 28 & $\mathrm{p}=0.012$
\end{tabular}

Note: Sensitivity $=17 / 35=48.6 \%$; Specificity $=28 / 35=80 \%$ Accuracy $=(17+28) / 70=64.3 \%$. PPV $=17 / 24=70.8 \% ;$ NPV $=28 / 46=60.9 \%$.

\section{Discussion}

This study showed the level of MMP-9 in spontaneous abortion group was higher than that in the normal pregnancy group, with a range of 735 to 2156.5 in the spontaneous abortion and 392.6 to 1520.6 in the normal pregnancy group, with significance $p=0.025$ (Table 3). This result was consistent with that of some studies done before, one of them by Zhao et al., which stated that MMP9 level would increase in implantation area where maternal decidua was invaded by trophoblasts. In spontaneous abortion decidua membrane destruction and sub chorionic excessive bleeding occur, followed by MMP-9 activation. Activated MMP-9 will cause damage of the basement membrane and thus resulting in a spontaneous abortion. Zhao et al in a study on murine also stated that MMP-9 increased in spontaneous abortion (6).

Table 3 also shows a wide range of MMP-9 levels in abortion group from 735 to 2156.5 . This result has many possibilities, one of them was the age of pregnancy when the abortion occurred, other possible factors are infection and chronic disease $(1,2,5,10,12)$.

Table 4 shows various variables correlation with MMP-9 level. There is a positive correlation between MMP-9 level with body mass index (BMI) in the spontaneous abortion group with $\mathrm{p}=0.025$ and in the normal group with $\mathrm{p}=0.028$, indicating BMI value has a positive correlation with increased levels of MMP-9. These results are consistent with previous researches that stated that the increase in spontaneous abortion was also associated with increased BMI (1-5). One of the studies found that women with moderate obesity (BMI 25 to 27.9 $\mathrm{kg} / \mathrm{m}^{2}$ ) had abortion more than women with normal weight (60\% vs. $27 \%, \mathrm{p}<0.05$ ).

The other data shown in Table 4 are the correlation between MMP-9 with leukocyte count. Increased leukocyte is one of proinflammatory state marker and is related with increased cytokines and proteolytic activity. All of these factors, together with TIMPs and other MMPs, have a role in activation of pro-MMP-9 to its active form. 
In this study the spontaneous abortion group had a value of $\mathrm{p}=0.044$, which means this value correlated significantly with the increased levels of MMP-9 (one side test using Spearman rank correlation). This result was consistent with that of previous studies that stated that MMP-9 activation involved many factors including inflammatory mediators, hormonal and enzymes (7-13).

Based on Table 5, it can be concluded that cut-off point of MMP-9 level was 1221.7 with a sensitivity of $48.6 \%$, specificity of $80 \%$, and accuracy of $60.9 \%$. Based on this result, MMP-9 can be considered as an alternative examination for screening pregnancies that have a high risk for spontaneous abortion.

\section{Conclusion}

MMP-9 level was higher in spontaneous abortion than in normal pregnancy and might be used as an alternative examination for screening in pregnancies that have a high risk for spontaneous abortion.

\section{References:}

1. Cunningham FG, Leveno KJ, Bloom SL, Hauth JC, Gilstrap III LC, Wenstrom KD. Abortion. Williams obstetrics. 22 ed. New York: McGraw Hill; 2005. p. 231-51.
2. Christiansen OB. Epidemiology of recurrent pregnancy loss. In: Carp HJA, editor. Recurrent pregnancy loss causes, controversies and treatment. 1 ed. London: Informa Healthcare; 2007. p. 1-13.

3. Luisi S, Lazzeri L, Genazzani AR. Endocrinology of pregnancy loss. In: HJA C, editor. Recurrent Pregnancy loss causes, controversies and treatment. London: Informa Healthcare; 2007. p. 79-87.

4. Barnea ER. Insight into early pregnancy: emerging role of the embryo. Am J Reprod Immunol. 2004;51:319-22.

5. Rosevear S. Bleeding in early pregnancy. In: James DK SJ, Weiner CP, Gonik B, editors. High Risk Pregnancy Management Options. 2nd ed. London: WB. Saunders; 2000. p. 61-89.

6. Zhao FX, Zhang YY, Liu RH, Li SM. Effect of blockage of co-stimulatory signal on murine abortion-prone model. Chinese Medical Journal. 2007; 120: 1247-50.

7. Zhao JX, Lin ZM, Yao HW, Wan YL. Analysis of the relationship between expressions of TF and MMP-9 and prognosis of breast cancer: Int J Gynecol Obstet. 2008;5:19-34

8. McCawley LJ, Matrisian LM. Matrix metalloproteinases. Curr Opin Cell Biol. 2001. 13: 534-40.

9. Strakova Z, Szmidt M, Srisuparp S, Fazleabas AT. Inhibition of matrix metalloproteinases prevents the synthesis of insulin-like growth factor binding protein-1 during decidualization in the baboon. Endocrinology. 2003; 144: 5339-46.

10. Staun-Ram E, Goldman S, Gabarin D, Shalev E. Expression and importance of matrix metalloproteinase 2 and 9 (MMP-2 and MMP-9) in human trophoblast invasion. Reprod Biol Endocrinol. 2004; 2: 59.

11. Lim KJH, Olusegun A, Ajjan RA, Li TC, Weetman AP, Cook ID. The role of $T$ helper cytokines in human reproduction. Fertil Steril. 2000; 73: 136-42.

12. Seval Y, Akkoyunlu G, Demir R, Asar M. Distribution patterns of matrix metalloproteinase (MMP)-2 and -9 and their inhibitors (TIMP-1 and TIMP-2) in the human decidua during early pregnancy. Acta Histochem. 2004; 106: 35362.

13. Yu YH, Wang ZJ. Relationship between matrix metalloproteinase-9 expression in syncytiotrophoblast and placenta pathologic change of intrauterine growth restriction. Chin J Perinat Med. 2003; 6: 215-8. 